\title{
IMPORTANCE OF ANTIBIOTIC PRODUCTION IN ANTAGONISM OF SELECTED STREPTOMYCES SPECIES TO TWO SOIL-BORNE PLANT PATHOGENS
}

\section{Craig S. Rothrock and David Gottlieb}

Department of Plant Pathology, University of Illinois, Urbana, Illinois 61801, U.S.A.

(Received for publication April 13, 1981)

\begin{abstract}
Antagonism of ten Streptomyces spp., five of which produce antibiotics, to the plant pathogens Rhizoctonia solani and Phytophthora megasperma var. sojae was studied. Antibiotic activity was detected in culture for the five antibiotic producers. S. griseus, S. hygroscopicus var. geldanus, and $S$. noursei produced wide zones of inhibition to $R$. solani and $P$. megasperma var. sojae. Similar activity was found for $S$. reticuli var. protomycicus to $P$. megasperma var. sojae. S. cellulosae reduced Rhizoctonia root rot on pea when sterile soil was infested simultaneously with the antagonist and $R$. solani. S. hygroscopicus gave almost complete disease control when the streptomycete was added 7 days prior to infesting the soil with $R$. solani. Several of the Streptomyces spp. reduced Phytophthora root rot on soybean when the streptomycetes were added to soil at the same time as $P$. megasperma var. sojae or 7 days prior to adding the pathogen. S. herbaricolor and $S$. coeruleofuscus gave the most consistent control. No relationship was found between reported antibiotic activity or antagonism on agar media and reduction in disease severity. Only S. hygroscopicus var. geldanus gave both control of Rhizoctonia root rot and large zones of inhibition on agar media when the streptomycetes were preincubated in soil for 7 days.
\end{abstract}

The means by which one organism inhibits the growth of another in soil is still a moot point and various mechanisms have been postulated to explain the process. Since some antagonistic microorganisms produce antibiotics in vitro which inhibit susceptible organisms, the general tendency is to point to the synthesis of antibiotics as one mechanism involved in antagonism in soil. Whether antibiotics are produced in normal unamended soils is not certain. Usually soil sterilization, or the addition of amendates or both are required for the synthesis of antibiotics in soil ${ }^{1 \sim 7)}$. Even if antibiotics were produced in soil, they might be inactivated by the physical, chemical, or microbial properties of soil ${ }^{2,3,8 \sim 12)}$. In this study, the antagonistic ability of ten Streptomyces spp. to two soil-borne plant pathogens is looked at in terms of their antibiotic producing ability.

\section{Materials and Methods}

Ten species of Streptomyces were used in this research. Five had been reported to produce antifungal antibiotics and five species had not been reported to produce antifungal antibiotics. All were obtained from Dr. T. G. Pridham of the Northern Regional Research Center, Peoria, Ill., U.S.A. (Table 1). The root rotting fungi were Rhizoctonia solani Kuhn (our own isolate) and Phytophthora megasperma Drechs sojae Hildeb, race 1, obtained from Dr. L. E. GRAY, U.S.D.A. collaborator at the University of Illinois. Eight streptomycetes were maintained on yeast extract-malt extract agar ${ }^{13)}$. Streptomyces cellulosae and Streptomyces herbaricolor were maintained on glycerol-asparagine agar ${ }^{13)}$ because of their poor sporulation on yeast extract-malt extract agar. $R$. solani was maintained on glucose-yeast extract agar ${ }^{14)}$ and $P$. megasperma in either soybean broth or on V-8 agar $\$ 248^{15)}$. Soybean broth was made by adding 1 soybean seed for each $10 \mathrm{ml}$ of distilled water. 


\section{In Vitro Experiments}

Four media were used to measure antagonism. The media compositions are expressed as amount of ingredient per liter. Media were Medium 1) Corn steep-soybean (CSSA); cerelose, $10 \mathrm{~g}$; soybean meal, $15 \mathrm{~g}$; NaCl, $5.0 \mathrm{~g} ; \mathrm{CaCO}_{3}$, $2.0 \mathrm{~g}$; corn steep, $10 \mathrm{ml}$; agar $20 \mathrm{~g}$; adjusted to $\mathrm{pH} 7.0$ before autoclaving. Medium 2) EMERSON's Agar; yeast extract, $1.0 \mathrm{~g}$; beef extract, $4.0 \mathrm{~g}$; Bacto-peptone, $4.0 \mathrm{~g}$; NaCl, $2.5 \mathrm{~g}$; cerelose, 10 g; agar $20 \mathrm{~g}$. Medium 3) Potato dextrose agar (PDA) (Difco), adjusted to $\mathrm{pH} 7.0$ before autoclaving. Medium 4) Soil extract agar (SEA) ${ }^{18)}$.

The ability of a streptomycete to inhibit the pathogen was determined by first streaking each medium with spores of the antagonist in a $1 \mathrm{~cm}$ wide band and incubating these cultures at $26^{\circ} \mathrm{C}$ for 5 days. A plug from the edge of a culture of $P$. megasperma var. sojae on V-8 agar or $R$. solani on glucose-yeast extract agar was then placed $1.5 \mathrm{~cm}$ or $3.0 \mathrm{~cm}$, respectively, from the streak and these plates incubated at $26^{\circ} \mathrm{C}$ for different durations depending on the pathogen and the medium.

Antagonism between Streptomyces spp. and the fungi was measured by the zone of inhibition, the distance between the edge of the streak and the point the pathogen stopped growing toward the streak. Percent inhibition of linear growth of the pathogen was also measured by comparing growth to non-streaked controls.

\section{Greenhouse Experiments}

$R$. solani inoculum was grown in glucose-asparagine liquid medium ${ }^{14)}$ at $26^{\circ} \mathrm{C}$ on a reciprocal shaker for 3 days. P. megasperma var. sojae inoculum was grown in soybean broth in stationary culture for 14 days at $26^{\circ} \mathrm{C}$. The cultures were filtered, mycelium resuspended in sterile distilled water, and homogenized. Inoculum levels used to infest soil were $0.45 \mathrm{~g}$ and $0.15 \mathrm{~g}$ per pot, equivalent to about $600 \mathrm{~g}$ oven dry weight of soil, for $R$. solani and P. megasperma var. sojae respectively.

Streptomycete inocula were grown in tryptone-yeast extract broth ${ }^{13)}$ on a reciprocal shaker for 48 hours at $26^{\circ} \mathrm{C}$. Inoculum was prepared by centrifugation at $4,500 \mathrm{rpm}$ (GSA rotor) for 10 minutes, decanting and the process repeated using sterile distilled water. Mycelium was suspended in sterile distilled water and homogenized. In all experiments $0.31 \mathrm{~g}$ of mycelium (wet weight) was used per pot.

The soil used in all experiments was a sterilized 3:2 mixture of field soil and sand (v: v). Inoculum was added to enough soil for a treatment, the soil evenly infested, dispensed into $10 \mathrm{~cm}$ diameter unglazed clay pots and five seeds planted per pot. Test plants were Glycine max L. 'Harasoy' for Phytophthora root rot and Pisum sativum L. 'Wando' for Rhizoctonia root rot. Soybean seeds were obtained from Dr. J. D. Paxton, University of Illinois. Pea seeds were purchased from W. Atlee Burpee Co. Pots were watered to saturation daily or when the soil surface became dry.

For experiments involving the incubation of the streptomycetes in soil prior to planting the seeds, the equivalent of $600 \mathrm{~g}$ oven dried soil was dispensed into a 1 liter Erlenmeyer flask and sterilized. Inoculum for each pot was added to the soil in the flask and shaken to infest the soil evenly. Sterile distilled water was added to bring the soil to $60 \%$ of the water holding capacity and the flasks incubated at $26^{\circ} \mathrm{C}$. All soils for a treatment were then combined and the soil treated as described earlier.

Emergence data were taken at weekly intervals following planting. Twenty-one days after planting, seedlings were removed and rated for disease severity. A 6 point disease severity index (DSI): 
0) No visible symptoms

1) Small superficial lesions on epicotyl

2) Large lesions girdling or almost girdling the epicotyl
3) Damping-off of some shoots

4) Postemergence damping-off

5) Preemergence damping-off

was used for rating the severity of Rhizoctonia root rot on peas. The disease severity index for Phytophthora root rot of soybeans was based on fresh root weight per pot, which was calculated as follows: average fresh root weight of the plants in a pot $\times$ percent plant stand. These data were transformed to a $0 \sim 5$ disease severity index consistent with the disease severity index for Rhizoctonia root rot by the following formula:

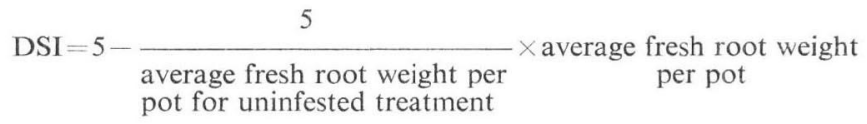

One seedling from each pot still containing living plants at the end of an experiment was selected to reisolate the pathogen and confirm its involvement in the disease.

Completely randomized designs were used in all experiments both in the greenhouse and in the laboratory. The data were statistically analyzed using DunCAN's multiple range test. For greenhouse experiments, a replicate consisted of one pot containing five seeds. All the experiments were done at least twice and usually more, and those described in this paper are examples of these results. Results were repeatable in many different experiments.

\section{Results}

Antagonism on Agar Media

Antagonism between some of the Streptomyces spp. and $R$. solani occurred on all the media used (Table 2). However the amount of inhibition varied with the medium. On EMERson's agar wide zones of inhibition were produced by S. hygroscopicus var. geldanus, S. griseus, and S. noursei (Table 2). On PDA the same three species produced zones of inhibition. A small zone of inhibition was produced on PDA by S. coeruleofuscus. Least inhibition occurred on SEA with only S. hygroscopicus var. geldanus producing a large zone of inhibition (Table 2). S. phaeochromogenes produced a small zone of inhibition. Those Streptomyces spp. producing zones of inhibition also inhibited the growth of $R$. solani to the greatest degree. All Streptomyces spp. inhibited the growth of $R$. solani to some degree on EMERSON's agar and PDA.

To determine antagonism to $P$. megasperma var. sojae the fungus was placed closer to the streak and incubated longer than $R$. solani because of its slower growth. On CSSA and PDA S. noursei, S. griseus, and S. hygroscopicus var. geldanus produced wide zones of inhibition (Table 3). S. reticuli var. protomycicus also produced a large zone of inhibition on PDA while $S$. herbaricolor produced a small zone (Table 3). No zone of inhibition was recorded for SEA because of the poor growth of the pathogen. Those Streptomyces spp. producing zones of inhibition also showed the greatest inhibition of growth. All of the streptomycetes inhibited the growth of P. megasperma to some degree on CSSA. On SEA only $S$. hygroscopicus var. geldanus and $S$. griseus significantly inhibited growth of the pathogen $(\mathrm{P}=0.01)$.

The presence and size of the zones of inhibition were used as criteria for the production of antibiotics by the various Streptomyces spp. There was a close relationship between the production of antibiotics as reported in the literature and our own data (Tables 1,2 and 3). Thus the antifungal activities (probably antibiotics) of the Streptomyces spp. were confirmed for one or more media against either $R$. solani 
Table 2. Antagonism by Streptomyces spp. to Rhizoctonia solani on agar media. ${ }^{1}$

\begin{tabular}{|c|c|c|c|}
\hline \multirow[b]{2}{*}{ Streptomyces spp. } & \multicolumn{3}{|c|}{ Zone of inhibition ${ }^{2}$} \\
\hline & $\begin{array}{l}\text { EMERSON's } \\
\quad \text { agar }\end{array}$ & 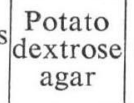 & $\begin{array}{l}\text { Soil } \\
\text { extract } \\
\text { agar }\end{array}$ \\
\hline S. cellulosae & 0 & 0 & 0 \\
\hline S. herbaricolor & 0 & 0 & 0 \\
\hline S. violaceoruber & 0 & 0 & 0 \\
\hline S. kitazawaensis ${ }^{3}$ & 0 & 0 & 0 \\
\hline $\begin{array}{l}\text { S. reticuli var. } \\
\text { protomycicus }\end{array}$ & 0 & 0 & 0 \\
\hline S. phaeochromogenes & 0 & 0 & 0.10 \\
\hline S. coeruleofuscus & 0 & 0.20 & 0 \\
\hline S. griseus $^{3}$ & 0.73 & 0.27 & 0 \\
\hline S. noursei $i^{3}$ & 1.47 & 1.03 & 0 \\
\hline $\begin{array}{l}\text { S. hygroscopicus var. } \\
\text { geldanus }{ }^{3}\end{array}$ & 2.10 & 2.43 & 0.50 \\
\hline \multicolumn{4}{|c|}{$\begin{array}{l}\text { Each treatment consisted of } 3 \text { replicates. } \\
\text { The zone of inhibition was determined by } \\
\text { measuring the distance }(\mathrm{cm}) \text { between the } \\
\text { pathogen and streptomycete streak after } 5 \\
\text { days incubation of the pathogen. }\end{array}$} \\
\hline
\end{tabular}

Table 3. Antagonism by Streptomyces spp. to Phytophthora megasperma var. sojae on agar media. ${ }^{1}$

\begin{tabular}{|c|c|c|}
\hline \multirow[b]{2}{*}{ Streptomyces spp. } & \multicolumn{2}{|c|}{ Zone of inhibition ${ }^{2}$} \\
\hline & $\begin{array}{l}\text { Corn steep- } \\
\text { soybean } \\
\text { agar }\end{array}$ & $\begin{array}{l}\text { Potato } \\
\text { dextrose } \\
\text { agar }\end{array}$ \\
\hline S. cellulosae & 0 & 0 \\
\hline S. coeruleofuscus & 0 & 0 \\
\hline S. phaeochromogenes & 0 & 0 \\
\hline S. violaceoruber & 0 & 0 \\
\hline S. kitazawaensis ${ }^{3}$ & 0 & 0 \\
\hline S. herbaricolor & 0 & 0.37 \\
\hline $\begin{array}{l}\text { S. reticuli var. } \\
\text { protomycicus }{ }^{3}\end{array}$ & 0 & 0.63 \\
\hline $\begin{array}{l}\text { S. hygroscopicus var. } \\
\text { geldanus }\end{array}$ & 1.00 & 1.10 \\
\hline S. griseus $^{3}$ & 1.50 & 0.70 \\
\hline S. noursei ${ }^{3}$ & 1.50 & 1.00 \\
\hline
\end{tabular}

1 Each treatment consisted of 3 replicates.

2 The zone of inhibition was determined by measuring the distance $(\mathrm{cm})$ between the pathogen and streptomycete streak after 9 days incubation of the pathogen for corn steep-soybean agar and 14 days for potato dextrose agar. The zone of inhibition on corn steep-soybean agar was calculated from two replicates.

3 Reported antibiotic producer.

or $P$. megasperma in four of the five reported producers. The fifth reported producer of this group, S. kitazawaensis did inhibit the plant pathogen Colletotrichum dematium (Pers. ex Fr.) Grove var. truncata (ScHw.) ARx.

\section{Antagonism in Soil}

When $R$. solani was added to soil at the same time as the various Streptomyces spp. and peas planted, only $S$. cellulosae, a non-producer gave significant disease control $(\mathbf{P}=0.05)$ (Table 4). The DSI was 3.40 for $S$. cellulosae infested soil and 3.98 in the absence of streptomycetes. When the 10 Streptomyces spp. were incubated separately in soil 7 days prior to adding the pathogen and planting, only $S$. hygroscopicus var. geldanus reduced the disease on peas significantly, $(\mathrm{P}=0.01)$ from a DSI 4.10 to 1.55 (Table 4). In the same experiments $S$. cellulosae did not decrease the disease.

The streptomycetes controlling Phytophthora root rot were more variable between experiments as was disease severity. When soil was infested at the same time with both the antagonist and pathogen, S. herbaricolor, $S$. coeruleofuscus, $S$. phaeochromogenes, and $S$. reticuli significantly reduced disease $(\mathbf{P}=$ 0.01) (Table 5). S. herbaricolor and $S$. coeruleofuscus were the most consistent at controlling disease. More species inhibited Phytophthora root rot than Rhizoctonia root rot. Incubation of the Streptomyces for 7 days prior to infesting the soil with Phytophthora resulted in significant disease control by $S$. coeruleofuscus, $S$. cellulosae, $S$. herbaricolor, $S$. violaceoruber, and $S$. kitazawaensis $(\mathrm{P}=0.01)$ (Table 5). 
Table 4. Effect of infesting soil with Streptomyces spp. on Rhizoctonia root rot of pea. ${ }^{1}$

\begin{tabular}{l|l|l}
\hline \multirow{2}{*}{\multicolumn{1}{c|}{ Streptomyces spp. }} & $\begin{array}{c}\text { Time of incubation } \\
\text { of Streptomyces } \\
\text { spp. in soil }\end{array}$ \\
\cline { 2 - 3 } & 0 days $^{2}$ & 7 days $^{3}$ \\
\hline S. cellulosae & $3.40 \mathrm{a}$ & $4.30 \mathrm{bc}$ \\
S. hygroscopicus var. geldanus & $3.55 \mathrm{ab}$ & $1.55 \mathrm{a}$ \\
S. griseus $^{4}$ & $3.62 \mathrm{ab}$ & $4.55 \mathrm{bc}$ \\
S. violaceoruber & $3.70 \mathrm{abc}$ & $4.50 \mathrm{bc}$ \\
S. herbaricolor & $3.78 \mathrm{abc}$ & $4.68 \mathrm{bc}$ \\
S. coeruleofuscus $_{\text {S. noursei }}{ }^{4}$ & $3.80 \mathrm{abc}$ & $4.75 \mathrm{c}$ \\
S. kitazawaensis $^{4}$ & $3.80 \mathrm{abc}$ & $4.52 \mathrm{bc}$ \\
none & $3.85 \mathrm{abc}$ & $4.25 \mathrm{bc}$ \\
S. phaeochromogenes & $3.98 \mathrm{bc}$ & $4.10 \mathrm{~b}$ \\
S. reticuli var. protomycicus & $4.22 \mathrm{c}$ & $4.55 \mathrm{bc}$ \\
\hline
\end{tabular}

1 Each treatment consisted of 8 replicates.

2 Means accompanied by the same letter are not significantly different at $\mathrm{P}=0.05$ according to Duncan's multiple range test. For the disease severity index see Methods. Uninfested soil had a DSI of 0.38 .

3 Means accompanied by the same letter are not significantly different at $\mathbf{P}=0.01$ according to Duncan's multiple range test. For the disease severity index see Methods. Uninfested soil had a DSI of 0.70 .

4 Reported antibiotic producer.
Table 5. Effect of infesting soil with Streptomyces spp. on Phytophthora root rot of soybean. ${ }^{1}$

\begin{tabular}{|c|c|c|}
\hline \multirow[t]{2}{*}{ Streptomyces spp. } & \multicolumn{2}{|c|}{$\begin{array}{l}\text { Time of incubation } \\
\text { of Streptomyces } \\
\text { spp. in soil }\end{array}$} \\
\hline & 0 days $^{2}$ & 7 days $^{2}$ \\
\hline S. herbaricolor & $1.412 \mathrm{a}$ & $1.405 \mathrm{ab}$ \\
\hline S. coeruleofuscus & $1.680 \mathrm{ab}$ & $0.881 \mathrm{a}$ \\
\hline S. phaeochromogenes & $1.740 \mathrm{ab}$ & $2.373 \mathrm{bc}$ \\
\hline S. reticuli var. protomycicus ${ }^{3}$ & $1.786 \mathrm{ab}$ & $2.254 \mathrm{bc}$ \\
\hline S. violaceoruber & $2.079 \mathrm{abc}$ & $1.472 \mathrm{ab}$ \\
\hline S. hygroscopicus var. geldanus ${ }^{3}$ & $2.122 \mathrm{abc}$ & $2.791 \mathrm{c}$ \\
\hline S. cellulosae & $2.416 \mathrm{bcd}$ & $1.113 \mathrm{a}$ \\
\hline none & $2.680 \mathrm{cde}$ & $2.815 \mathrm{c}$ \\
\hline S. griseus $^{3}$ & $2.992 \mathrm{de}$ & $2.262 \mathrm{bc}$ \\
\hline S. kitazawaensis ${ }^{3}$ & $3.010 \mathrm{de}$ & $1.584 \mathrm{ab}$ \\
\hline S. noursei $i^{3}$ & $3.213 \mathrm{de}$ & $2.610 \mathrm{c}$ \\
\hline
\end{tabular}

1 Each treatment consisted of 8 replicates.

2 Means accompanied by the same letter are not significantly different at $\mathrm{P}=0.01$ according to Duncan's multiple range test.

3 Reported antibiotic producer.

Establishment of the Streptomyces species in soil was evident by the growth and sporulation of some species on the seed coats of pea and soybean during the experiments. The streptomycetes also grew on the soil during the

incubation period. There was no apparent relationship between the degree of growth on the seed coats or on the soil during the period of incubation and disease severity.

No relationship was found for $R$. solani or $P$. megasperma var. sojae between reported antifungal antibiotic production and disease severity in soil that had been infested with the Streptomyces spp. and the pathogens. A poor correlation between antagonism on agar media and disease severity in soil infested with the respective Streptomyces spp. was also found.

\section{Discussion}

Although the terms antagonism and antibiosis have been differentiated in their use until now, the data (Tables 2 and 3) indicate that the antagonism of the Streptomyces species against the pathogens in vitro is due primarily to the diffusion of an antibiotic into the medium. Four of the five species of Streptomyces that have been reported to produce an antifungal antibiotic greatly inhibited fungal growth and caused relatively large zones of inhibition to at least one of the pathogens. Though $S$. kitazawaensis had no activity against the two pathogens used, it did inhibit a species of Colletotrichum. The inhibition of growth by the remaining species that had not previously been reported to make antifungal compounds could be attributed either to the synthesis of very low concentration of antibiotics or the effect of some other factors limiting the growth of the two fungi.

The data in Tables 2 and 3 also illustrate the importance of nutrients in the synthesis of antibiotics. Soil extract agar supported only moderate growth and caused few zones of inhibition and little inhibition 
of growth. This is in sharp contrast to the large amount of inhibition produced on the "rich" media, EMERSON's agar, CSSA, and PDA. This data support the results of our previous studies indicating that in soil Streptomyces spp. did not produce antibiotics unless either some plant products were added to soil, the soil sterilized or both.

A few of the Streptomyces spp. gave significant reduction of the two diseases (Tables 4 and 5). No obvious relationship was found between the ability of a species to reduce disease and its reported antibiotic activity or antagonism in vitro. Proponents of antibiotic production playing a role in antagonism in soil have suggested that antibiotic production may play a significant role in antagonism at the microhabitat level and thus not be present in sufficient levels for detection. Our data suggest that those Streptomyces spp. which produce antibiotics in vitro show no greater antagonism in soil than those which fail to produce antibiotics suggesting that antibiotics don't play a significant role in antagonism. Situations in which both occur such as when S. hygroscopicus var. geldanus was incubated in soil prior to adding $R$. solani and the inhibition of the fungus on media are probably fortuitous. The use of previously sterilized soil would have favored antibiotic production in soil and thus the role of antibiotic production in antagonism should have been exhibited if it occurred. The ecological significance of antibiotic producing ability is still uncertain but it appears to play no significant role in antagonism.

\section{References}

1) Evans, E. \& D. Gottlieb: The role of gliotoxin in the soil. Phytopathology 42: 465 466, 1952

2) Gottlieb, D. \& P. Siminoff: The production and role of antibiotics in the soil. II. Chloromycetin. Phytopathology 42: $91 \sim 97,1952$

3) Gottlieb, D.; P. Siminoff \& M. M. Martin: The production and role of antibiotics in soil. IV. Actidione and clavacin. Phytopathology 42: 493 496, 1952

4) Gregory, K. F.; O. N. Allen, A. J. Riker \& W. H. Peterson: Antibiotics as agents for the control of certain damping-off fungi. Am. J. Bot. 39: 405 415, 1952

5) Wright, J. M.: Production of gliotoxin in unsterilized soil. Nature 170: 673 674, 1952

6) Wright, J. M.: The production of antibiotics in soil. II. Production of griseofulvin by Penicillium nigricans. Ann. Appl. Biol. 43: 288 296, 1955

7) Wright, J. M.: The production of antibiotics in soil. III. Production of gliotoxin in wheatstraw buried in soil. Ann. App. Biol. 44: 461 466, 1956

8) Jefferys, E. G.: The stability of antibiotics in soils. J. Gen. Microbiol. 7: 295 312, 1952

9) Martin, M. \& D. Gottlieb: The production and role of antibiotics in soil. V. Antibacterial activity of five antibiotics in the presence of soil. Phytopathology 45: 407 408, 1955

10) Pinck, L. A.; W. F. Holton \& F. E. Allison: Antibiotics in soil. I. Physico-chemical studies of antibioticclay complexes. Soil Sci. $91: 22 \sim 28,1961$

11) Pinck, L. A.; O. A. Soulides \& F. E. Allison: Antibiotics in soils. II. Extent and mechanism of release. Soil Sci. 91: 94 99, 1961

12) Wright, J. M. \& J. F. Grove: The production of antibiotics in soil. V. Breakdown of griseofulvin in soil. Ann. Appl. Biol. 45: 36 43, 1957

13) Shirling, E. B. \& D. Gotrlieb: Methods for characterization of Streptomyces species. Internal. J. Syst. Bacteriol. 16: 313 340, 1966

14) Gottlieb, D. \& J. L. Van Etten: Changes in fungi with age. I. Chemical composition of Rhizoctonia solani and Sclerotium bataticola. J. Bacteriol. 91 : $161 \sim 168,1966$

15) Turte, J.: Plant Pathological Methods. p. 73, Burgess Publishing Company, Minneapolis, 1969

16) LochHeAD, A. G.: Qualitative studies of soil microorganisms. III. Influence of plant growth on the character of the bacterial flora. Can. J. Res. 18 (c) : $42 \sim 53,1940$ 